\title{
An improved species distribution model for Scots pine and downy oak under future climate change in the NW Italian Alps
}

\author{
Giorgio Vacchiano $\cdot$ Renzo Motta
}

Received: 16 March 2014 / Accepted: 10 November 2014 / Published online: 19 December 2014

(C) INRA and Springer-Verlag France 2014

\begin{abstract}
- Key message Warming will induce an upward displacement of Scots pine, but this can be partially mitigated by maintaining a more intense land use.

- Context Scots pine is currently declining in most inner alpine sectors of southern Europe. The relative contribution of climate, land use change, and disturbances on the decline is poorly understood. What will be the future distribution of the species? Is vegetation shifting toward oak-dominated forests? What is the role of extreme drought years?

- Aims The aims of the study were to determine drivers of current distribution of Scots pine and downy oak in Aosta valley (SW Alps), to extrapolate species distribution models to year 2080 (Special Report on Emissions Scenarios (SRES) A1B), and to assess the correlation between pine vitality after the extreme droughts of 2003 and 2006, and modeled longterm vegetation changes.

- Methods Ensemble distribution models were created using climate, topography, soil, competition, natural disturbances, and land use. Species presence was derived from a regional forest inventory. Pine response to drought of 2003-2006 was assessed by Normalized Difference Vegetation Index (NDVI) differencing and correlated to modeled cover change between 2080 and present.

- Results Scots pine and downy oak were more likely to occur under higher climatic aridity. Scots pine was also associated to
\end{abstract}

Handling Editor: Thomas WOHL GEMUTH

Contribution of the coauthors GV designed the study, conducted the analysis, and wrote the paper. RM supervised the work and revised the manuscript.

Electronic supplementary material The online version of this article (doi:10.1007/s13595-014-0439-4) contains supplementary material, which is available to authorized users.

G. Vacchiano $(\bowtie) \cdot$ R. Motta

Dipartimento di Scienze Agrarie, Forestali e Alimentari, Università degli Studi di Torino, Largo Braccini 2, 10095 Grugliasco, TO, Italy e-mail: gvacchiano@gmail.com higher wildfire frequency, land use intensity, and lack of competition. In a warming scenario, pine experienced an elevational displacement. This was partially counteracted if no land abandonment was hypothesized. Downy oak cover increased in all scenarios. Short- and long-term drought responses of pine were unrelated.

- Conclusion Warming will induce an upward displacement of pine, but this can be partially mitigated by maintaining a more intense land use. The drought-induced decline in pine vitality after extreme years did not overlap to the modeled species response under climate warming; responses to shortterm drought must be more thoroughly understood in order to predict community shifts.

Keywords Drought · Pine decline · Pinus sylvestris L. . Potential niche · Quercus pubescens Willd · Succession

\section{Introduction}

Scots pine (Pinus sylvestris L.) forests at the southern edge of their distribution are currently facing decline and succession, resulting from a combination of climate warming, land use changes, and increased abiotic and biotic disturbances (Gimmi et al. 2010; Vacchiano et al. 2012).

From a physiological standpoint, drought has been identified as the primary driver of pine decline, as it affects foliage production, carbon allocation (Galiano et al. 2010), cambial activity (Eilmann et al. 2011; Oberhuber et al. 2011), hydraulic capacity (Sterck et al. 2008), and the likelihood of xylem cavitation (Martinez-Vilalta and Piñol 2002). Additionally, drought can predispose weakened trees to inciting mortality agents, such as mistletoe, bark beetles, or root-rot fungi (Dobbertin et al. 2007; Gonthier et al. 2010; Rigling et al. 2010; Sangüesa-Barreda et al. 2013), and reduce seedling recruitment and survival (Matias and Jump 2014).

On top of this, at the landscape level, Scots pine forests in southern Europe have recently experienced a decrease in 
management intensity, shifting from open-canopy, even-aged stands maintained by broadleaves coppicing, wood pasture, litter raking, and pitch collection (Gimmi et al. 2007) to denser forests following depopulation of mountain areas and abandonment of traditional land use practices. Under such scenario, succession by mid-tolerant species such as downy oak (Quercus pubescens Willd.) is favored over Scots pine regeneration (Urbieta et al. 2011; Rigling et al. 2013). Both mechanisms, land use changes and climate extremes, are at work at the same time (Gimmi et al. 2010), determining feedbacks and interactions difficult to disentangle and providing a challenge for forecasting future vegetation patterns.

Recession of Scots pine forests in southern European landscapes would affect the provision of important ecosystem services, such as protection from hydrogeological hazards, plant and animal diversity, timber, and recreation. A shift from Scots pine to oak can also be problematic because of the loss of useful life traits, as the ability to rapidly colonize open or disturbed ground (Vacchiano et al. 2013). Predictions of future vegetation changes and knowledge of the suitability of pine vs. oak to expected environmental conditions will help managers in developing adaptation strategies to sustain the fulfillment of the desired forest functions (Chmura et al. 2011).

The aims of this work were (1) to detect drivers of current pine and oak occurrence in a mountain region of the southwestern Alps, by fitting species distribution models (SDM) on climate, soil, land use, stand structure, and disturbance-related predictors; (2) to apply the models using future (2080) scenarios, in order to assess if and where vegetation shifts are likely to occur under climate and management changes; and (3) to compare the effects of the Europe-wide drought events of 2003 and 2006 (Thabeet et al. 2010) on Scots pine vitality against SDM predictions in 2080, in order to assess the potential role of extreme drought response as an early warning of future vegetation changes.

\section{Methods}

\subsection{Study species}

Scots pine is the most widespread coniferous species in Europe and the most widespread pine in the world (Mirov 1967). Scots pine is a species of continental climates, able to grow in areas with annual precipitation ranging from 200 to $1800 \mathrm{~mm}$ (Burns and Honkala 1990). The upper/northern and lower/ southern limits of the species correspond with isotherms $-1{ }^{\circ} \mathrm{C}$ (mean temperature of the coldest month) and $+33{ }^{\circ} \mathrm{C}$ (mean temperature of the warmest month), respectively (Dahl 1998), even if pine can tolerate more extreme temperatures without tissue damage, especially at the cold end $\left(-90^{\circ} \mathrm{C}\right.$ : Sakai and Okada 1971).
Scots pine is a light-demanding, early seral species that can establish both in acid and limestone soils (Richardson 1998; Debain et al. 2003). Its ecology is largely characterized by stress tolerance. On the one hand, this allows it to occupy a range of habitats that are unfavorable to other tree species, through tolerating various combinations of climatic and edaphic stress (Richardson 1998). On the other hand, this implies that Scots pine is excluded from more favorable sites through competition. In recent decades, it was favored by past fires (Gobet et al. 2003), by heavy forest cuts, and by the recent increase of fallow lands (Farrell et al. 2000; Kräuchi et al. 2000; Caplat et al. 2006; Picon-Cochard et al. 2006). In the absence of disturbances, it will eventually be overgrown or replaced by broadleaves or mixed broad-leaved coniferous forest. However, in the drier, central alpine sectors ( $<700 \mathrm{~mm}$ year $^{-1}$ rainfall), Scots pine often forms stable communities due to limited competiveness of other conifer tree species (Ozenda 1985).

Scots pine populations are negatively affected by drought in all demographic processes, i.e., regeneration (Galiano et al. 2013, Carnicer et al. 2014), growth (Vilà-Cabrera et al. 2011), and mortality (Dobbertin et al. 2005; Bigler et al. 2006). On the other hand, downy oak exhibits better ecophysiological adaptations (Nardini and Pitt 1999; Eilmann et al. 2006, 2009; Zweifel et al. 2009) and higher growth (Weber et al. 2008) under comparable climate conditions. Oaks also have an advantage over Scots pine in the regeneration phase following stand-replacing fire, owing to their resprouting ability - as opposed to limitations in Scots pine regeneration due to short dispersal distance and obligate seeder traits (Moser et al. 2010; Vacchiano et al. 2013). Such differences, and the fact that oaks are characterized by lower shade intolerance, make them a suitable species for secondary succession of declining or outcompeted pine stands.

\subsection{Study area}

The study area covers the Aosta Valley region in Northwestern Italy $\left(3262 \mathrm{~km}^{2}\right)$ (Fig. 1). Topography is shaped by a main east-west-oriented valley with several north-south protrusions. Mean annual temperature in Aosta $\left(45^{\circ} 26^{\prime} \mathrm{N}, 7^{\circ} 11^{\prime}\right.$ E, $583 \mathrm{~m}$ a.s.l.) is $10.9^{\circ} \mathrm{C}$ (years $1961-1990$; Tetrarca et al. 1999). Climate is warm-summer continental (Dfb) according to the Köppen classification (Peel et al. 2007); July and January monthly means may differ by as much as $22^{\circ} \mathrm{C}$. Mean annual rainfall in Aosta amounts to very low values in comparison with localities in other central Alpine valleys (494 mm, years 1961-1990; Biancotti et al. 1998), with a period of water deficit (Bagnouls and Gaussen 1957) extending from June to September. Winter precipitation usually comes as snow. The study area exhibits both crystalline (granites) and metamorphic bedrocks, but most landscape is covered by quaternary deposits of glacial, gravitative, or 
colluvial origin. Soils belong to the series of western and central Alpine soil on igneous and metamorphic rocks (Costantini et al. 2004) and are mostly represented by shallow soils (Lithic, Umbric, and Dystric Leptosols), eroded soils (Eutric and Calcaric Regosols), acid soils with organic matter, iron oxides and aluminum accumulation (Dystric Cambisols, Haplic Podzols, Humic Umbrisols), or alluvial soils (Eutric Fluvisols).

Scots pine stands in the study area cover 5372 ha (Gasparini and Tabacchi 2011), i.e., $6 \%$ of the total forest area, and thrive on both acidic and basic substrates of wellexposed, bottom to mid-elevation slopes. Stands dominated by Scots pine are mostly young, averaging 920 trees per hectare (TPHA) and a basal area (BA) of $26 \mathrm{~m}^{2} \mathrm{ha}^{-1}$ (Gasparini and Tabacchi 2011). Quadratic mean diameter (QMD) is $21 \mathrm{~cm}$, but trees larger than $35 \mathrm{~cm}$ are extremely rare (about $2 \%$ ) (Camerano et al. 2007). Stand top height can vary from 10 to $25 \mathrm{~m}$ according to site fertility (Vacchiano et al. 2008). Depending on successional stage and climatic factors, species composition may range from $100 \%$ pine (especially on recently disturbed sites or dry, southern slopes) to mixtures with Swiss mountain pine (Pinus montana Mill.), European larch (Larix decidua Mill.), Norway spruce (Picea excelsa Karst.), silver fir (Abies alba Mill.), beech (Fagus sylvatica L.), sessile oak (Quercus petraea (Mattus.) Liebl), European chestnut (Castanea sativa Mill.), and mostly with downy oak, which has similar thermal and moisture needs.
Downy oak stands cover 3468 ha in the study area (Gasparini and Tabacchi 2011), at elevations of 300-1200 m (but up to $1500 \mathrm{~m}$ on rocky outcrops and $1800 \mathrm{~m}$ for isolated individuals), predominantly on shallow soils and carbonatic substrates. Xerophilous stands on south-facing slopes are sparse and slow growing (1000 TPHA, BA $20 \mathrm{~m}^{2} \mathrm{ha}^{-1}$ ), with young individuals often developed from former coppices, grazed woodland, or after invasion on abandoned fallow lands (QMD 10-25 cm, mean height 5-10 m) (Gasparini and Tabacchi 2011). Just as in Scots pine, meso-xerophilous stands on north-facing slopes exhibit higher growth (mean height $10-15 \mathrm{~m}$ ) and mixture degree. Scots pine and downy oak can replace each other in the course of forest dynamics, e.g., by regeneration of pine in sparse and degraded oak woodlands or by succession of closed-canopy, or declining, pine forests to more tolerant oak (Zavala and Zea 2004).

\subsection{Drivers of pine and oak distribution}

In order to model the occurrence of Scots pine and downy oak in the study area, we used a diverse set of explanatory variables including vectorial as well as raster information at different spatial resolutions. All variables were resampled at a common spatial resolution of $1 \mathrm{~km}$, i.e., the coarsest resolution among all explanatory variables, and clipped to a land use mask of current forest distribution. Since the model could be calibrated against current vegetation conditions only.
Fig. 1 Location of the study region and area covered by forests (in green)

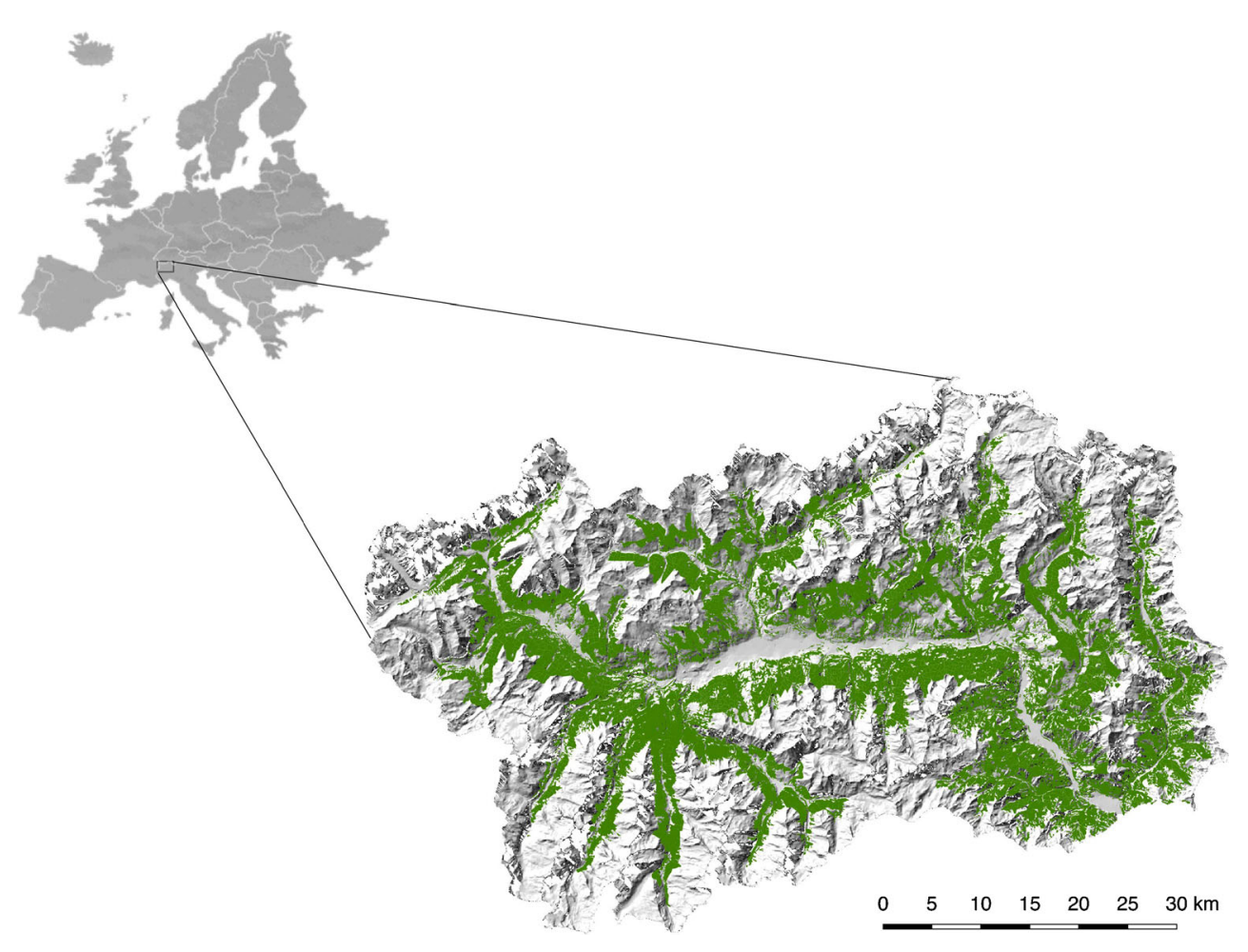


Rasterization of vector layers and raster resampling were carried out by aggregating to cell means if raster grain was finer than $1 \mathrm{~km}$ and by bilinear (for continuous layers) or nearest neighbor interpolation (for categorical layers) if grain exceeded $1 \mathrm{~km}$. Explanatory variables included the following (Figure S1):

(1) Elevation, slope, aspect, southness (i.e., a linearization of aspect: Chang et al. 2004), and topographic position index (TPI: Guisan et al. 1999) computed from a 10-m digital terrain model. A higher TPI is indicative of ridges or hilltops.

(2) Climate means (years 1961-1990) at a 1-km resolution, extracted from the WorldClim database (Hijmans et al. 2005). These included mean, minimum, and maximum yearly temperatures (TMIN, TMEAN, TMAX), yearly precipitation $(\mathrm{P})$, precipitation cumulated in the growing season (GSP; April-September), and yearly solar radiation (RAD). Additionally, using mean, minimum, and maximum monthly temperature grids, we computed growing degree days (GDD; base temperature $=5^{\circ} \mathrm{C}$ ) (Fronzek et al. 2011) and an aridity index (AI) as the difference between monthly precipitation and potential evapotranspiration (PET). PET for month $i$ was computed as after Zimmermann et al. (2007).

PETi $=0.0023 \operatorname{RAD}_{i}\left(T \operatorname{MEAN}_{i}+17.8\right) \frac{\left(T \mathrm{MAX}_{i}-T \mathrm{MIN}_{i}\right)}{2}$ days

(3) Soil variables at a $1-\mathrm{km}$ resolution, extracted from the European Soil Bureau (European Soil 1999). We selected variables potentially important for tree establishment and growth, namely available water capacity (AWC) of the topsoil, accumulated soil temperature class (ATC), total organic carbon (OC) of the topsoil, base saturation (BS), erodibility (ERO), depth to rock (DR), dominant surface textural class (TEXT), and volume of stones (VS). All variables were coded as dummy values.

(4) Natural disturbances, such as landslides or severe soil erosion (source: Corine Land Cover 1990 raster coverage, resolution $500 \mathrm{~m}$ ), avalanche tracks, and wildfires $>10$ ha for the years 1961-1991 (sources: Regione Autonoma Valle d'Aosta, Ufficio Neve e Valanghe, and Regione Autonoma Valle d'Aosta, Corpo Forestale Regionale, Nucleo Antincendo Boschivi).

(5) Competition by the pre-existing canopy, assessed by extracting the Normalized Difference Vegetation Index (NDVI) from a Landsat 5 Thematic Mapper image (path 195, row 28) taken on June 30, 1987 (resolution $30 \mathrm{~m}$ ). The acquisition period was chosen as to be at the peak at the growing season; the image had $10 \%$ cloud cover, but clouds were clustered over high elevation, unforested terrain. The image was first converted to top of the atmosphere radiance using standard equations and calibration parameters obtained from the metadata of the scene (Chander et al. 2009). Then, we computed NDVI using band TM4 (near infrared) and band TM3 (visible red) and used it as a proxy of standing forest biomass (Tucker 1979; Pettorelli et al. 2005). As an additional index of competition by forest vegetation, we used percent tree cover from the recently released Landsat vegetation continuous field (VCF) dataset (Sexton et al. 2013), at a resolution of $30 \mathrm{~m}$, based on a Landsat 5 TM image acquired on July 27, 2001.

(6) Land use intensity was assessed by using proxy variables, i.e., total road length and total building surface per 500-m pixel, as extracted from a vector regional map. Moreover, the degree of land abandonment was estimated at the municipality level by the percent variation in resident population in the period 1951-1991 (source: ISTAT).

In order to limit collinearity of independent variables, predictors exhibiting a Pearson's correlation coefficient $>|0.9|$ were excluded from further analysis.

\subsection{Model runs under future scenarios}

Simulation experiments for the future projections of species distribution relied on the same set of explanatory variables. However, values for variables used in future scenarios were chosen as follows:

(1) Climate means for the 2080 decade were extracted from 30 -arcsec gridded simulations by the ECHAM5/MPIOM model from the Max-Planck Institute for Meteorology, Germany (Raible et al. 2006), under the high emission scenario Special Report on Emissions Scenarios (SRES) A1B. Under the assumption of a constant solar radiation, we computed GDD, GSP, PET, and AI from the ECHAM-5 grids. For the 2080 scenario, we did not extrapolate the model to pixels exhibiting AI values exceeding the range of current ones (Elith and Leathwick 2009).

(2) Fire frequency and size are supposedly responsive to climate change (Moriondo et al. 2006). In order to simulate the influence of fire preceding the 2080 decade, we used wildfire polygons for the years 1981-2000, i.e., a period that included several extreme fire seasons resulting in a +39 and $+26 \%$ increase in the frequency and total area burned, respectively, by large fires ( $>10 \mathrm{ha})$ relative to $1961-1980$.

(3) We simulated two alternative land use scenarios: (1) urbanization and land abandonment, i.e., every municipality was assigned a "business as usual" scenario of 
population change using figures for the period 19511991, and (2) maintenance of high land use, i.e., all municipalities were assigned $0 \%$ variation in population respective to 1951 , thereby assuming a continued presence of man and its activities at all rural settings.

Soil characteristics are also responsive to climate change (Singh et al. 2011); however, we kept these variables at current conditions for the 2080 simulation, since no quantitative scenarios are available to estimate future changes. Altogether, three scenarios were simulated: current conditions, 2080 climate with unchanged land use, and 2080 climate with intense land use.

\subsection{Model building}

Presence/absence of pine and oak in the years 1992-1994 served as a response variable, which we extracted from a regional forest inventory based on a $500-\mathrm{m}$ regular grid. At every grid node, the species and diameter at breast height $(\mathrm{DBH})$ of each living tree $(\mathrm{DBH}>7.5 \mathrm{~cm})$ were measured within a variable-radius circular plot (radius $8-15 \mathrm{~m}$ depending on tree density). Plot coordinates were recorded to the nearest meter. Scots pine and downy oak were labeled as present where at least one tree of each species was recorded and absent otherwise.

We assumed that both pine and oak distribution are in equilibrium with the environment (Rohde 2005). For this reason, and because our aim was to model potential niche, no migration constraints were included in the model.

We used an ensemble modeling approach (Araujo and New 2007), by fitting and averaging predictions obtained by a generalized linear model (GLM), artificial neural network (ANN), and multiple adaptive regression spline (MARS) using the same set of responses, predictors, and scenarios. Model specifications were as follows: (a) for GLM, a backward stepwise algorithm was used, based on Akaike Information Criterion (AIC); (b) for ANN, the initial number of crossvalidations to find best size and decay parameters was set to five; and (c) for MARS, the cost per degree of freedom charge was set to 2 , and the model was pruned in a backward stepwise fashion. All models were fit on a binomial distribution with logit link, without interactions between predictors, and using a maximum of 100 iterations.

For each of the three models, we computed variable importance ratings and response curves. To do so, all variables but one are set constant to their median value, and only the remaining one is allowed to vary across its whole range. In the case of categorical variables (e.g., soil), the most represented class was used. The variations observed and the curve thus obtained show the sensibility of the model to that specific variable.

We carried out $k$-fold cross-validation of the model by subdividing the data into a 3:1 proportion $(k=4)$. Model specificity and sensitivity were computed for the selected thresholds; the threshold to convert continuous predictions into binary ones was iteratively chosen to maximize the area under the curve (AUC).

The ensemble prediction was computed from all model realizations with AUC $>0.75$. The probability of occurrence for the ensemble prediction was the mean of the selected models' predictions, weighted by the model AUC. Model residuals were scrutinized to detect the absence of trends against predicted values and independent variables; a variogram was fitted to assess the degree of residual spatial autocorrelation. Ensemble models were run for the whole study region to obtain a map of potential species distribution under current and future climate, assuming niche conservationism (Wiens et al. 2010). We classified simulated presence/absence of both species using an occurrence probability threshold of 0.6 and assessed projected area changes and elevational shifts in the distribution of pine and oak under the climate change and climate change + intense land use scenarios. All analyses were carried out using the biomod2 package (Thuiller et al. 2013) for R (R Development Core Team 2013).

\subsection{Effect of extreme drought events}

The response of extant Scots pine forests to drought events in years 2003 and 2006 was assessed by the temporal difference in NDVI ( $\triangle$ NDVI: year of drought - year before drought). NDVI was computed from two 16-day maximum value composite (MVC) MODIS images (resolution 30 arcsec) taken at the end of the summer (Julian days 226-241). Cloud cover of the MVC was between 1 and $4 \%$ for the four images. Pixels with a quality analysis score of 2 and 3 (i.e., targets covered by snow/ice or cloudy pixel) as well as NDVI lower than 0.2 or null (open water) were filtered out (Vacchiano et al. 2012).

In order to distinguish reflectance anomalies from random or systematic error (Morisette and Khorram 2000), we classified as "decline" all pixels with $\Delta \mathrm{NDVI}<$ (mean -3 standard deviations), as computed from the full scene (Fung and LeDrew 1988; Vacchiano et al. 2012). Finally, we compared the modeled change in pine occurrence probability (2080current) of decline vs. non-decline pixels by means of Wilcoxon signed-rank test (Sokal and Rohlf 1995).

\section{Results}

Scots pines were detected in 460 (27\%) out of 1730 inventory plots, and downy oak in $181(10 \%)$. After screening for collinearity, 18 predictors were retained for subsequent analyses (Table 1). Since most climate-related variables were correlated to each other and to elevation, we retained only aridity index (AI) as the main climate predictor; Pearson's

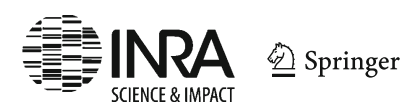


Table 1 Explanatory variables used in this study (minimum, maximum, mean, standard error), computed for currently forested areas only

\begin{tabular}{|c|c|c|c|c|c|}
\hline Code & Description & Range & Mean & Units & Resolution \\
\hline Bio01 & Mean annual temperature ${ }^{\mathrm{a}}$ & $-0.6-11.1$ & 4.9 & ${ }^{\circ} \mathrm{C}$ & $30 \operatorname{arcsec}$ \\
\hline Bio05 & Max temperature of warmest month ${ }^{\mathrm{a}}$ & $10.8-26.7$ & 18.5 & ${ }^{\circ} \mathrm{C}$ & $30 \operatorname{arcsec}$ \\
\hline Bio06 & Min temperature of coldest month ${ }^{\mathrm{a}}$ & $-10.8--2.9$ & -6.9 & ${ }^{\circ} \mathrm{C}$ & $30 \operatorname{arcsec}$ \\
\hline Bio07 & Temperature annual range ${ }^{\mathrm{a}}$ & $21.3-29.6$ & 25.4 & ${ }^{\circ} \mathrm{C}$ & $30 \operatorname{arcsec}$ \\
\hline Bio10 & Mean temperature of warmest quarter ${ }^{\mathrm{a}}$ & $6.4-20$ & 12.8 & ${ }^{\circ} \mathrm{C}$ & $30 \operatorname{arcsec}$ \\
\hline Bio11 & Mean temperature of coldest quarter ${ }^{\mathrm{a}}$ & $-7.2-2$ & -2.8 & ${ }^{\circ} \mathrm{C}$ & $30 \operatorname{arcsec}$ \\
\hline Bio12 & Annual precipitation $^{\mathrm{a}}$ & $796-1828$ & 1263.3 & $\mathrm{~mm}$ & $30 \operatorname{arcsec}$ \\
\hline Bio18 & Precipitation of warmest quarter ${ }^{\mathrm{a}}$ & $22-465$ & 335.6 & $\mathrm{~mm}$ & $30 \operatorname{arcsec}$ \\
\hline GDD & Growing degree days above $5^{\circ} \mathrm{C}$ & $257-2656$ & 1181.2 & ${ }^{\circ} \mathrm{C}$ & $30 \operatorname{arcsec}$ \\
\hline GSP & Precipitation April-September & $437-913$ & 663.5 & $\mathrm{~mm}$ & $30 \operatorname{arcsec}$ \\
\hline$A I$ & Aridity index (Bio12 -PET) & $-638-1252$ & 311.0 & $\mathrm{~mm}$ & $30 \operatorname{arcsec}$ \\
\hline DTM & Elevation $^{\mathrm{b}}$ & $308-2493$ & 1514.3 & m a.s.l. & $10 \mathrm{~m}$ \\
\hline Slope & Slope from DTM & $0-44$ & 17.0 & $\circ$ & $10 \mathrm{~m}$ \\
\hline$T P I$ & Topographic position Index & $-3.0-3.1$ & -0.4 & - & $10 \mathrm{~m}$ \\
\hline Southness & Linearization of aspect & $0-180$ & 97.2 & $\circ$ & $10 \mathrm{~m}$ \\
\hline$A T C$ & Accumulated Soil temperature class ${ }^{\mathrm{c}}$ & $1-3$ & - & Dummy & $1 \mathrm{~km}$ \\
\hline$A W C$ & Available water capacity in the topsoil ${ }^{\mathrm{c}}$ & $1-3$ & - & Dummy & $1 \mathrm{~km}$ \\
\hline BS & Soil base saturation $^{\mathrm{c}}$ & $1-2$ & - & Dummy & $1 \mathrm{~km}$ \\
\hline$D R$ & Soil depth to rock ${ }^{\mathrm{c}}$ & $1-4$ & - & Dummy & $1 \mathrm{~km}$ \\
\hline$E R O$ & Soil erodibility $^{\mathrm{c}}$ & $3-5$ & - & Dummy & $1 \mathrm{~km}$ \\
\hline$O C$ & Organic carbon in the topsoil ${ }^{\mathrm{c}}$ & $1-3$ & - & Dummy & $1 \mathrm{~km}$ \\
\hline TEXT & Soil texture (from coarse to fine) ${ }^{\mathrm{c}}$ & $0-2$ & - & Dummy & $1 \mathrm{~km}$ \\
\hline$V S$ & Volume of stones in the soil ${ }^{\mathrm{c}}$ & $0-2$ & - & Dummy & $1 \mathrm{~km}$ \\
\hline Avalanches & Number of avalanche polygons ${ }^{\mathrm{b}}$ & $0-3$ & 0.1 & Count & $10 \mathrm{~m}$ \\
\hline Wildfires & Number of fire polygons, $1961-1990^{\mathrm{b}}$ & $0-3$ & 0.0 & Count & $10 \mathrm{~m}$ \\
\hline Erosion & Total area subject to landslide or erosion ${ }^{\mathrm{d}}$ & $0-14523$ & 656.9 & $\mathrm{~m}^{2}$ & $500 \mathrm{~m}$ \\
\hline Depop & Change in population $1951-1991^{\mathrm{e}}$ & $-59-135$ & 2.1 & $\%$ change & Municipality \\
\hline Roads & Total road length ${ }^{\mathrm{b}}$ & $0-8485$ & 1812.0 & $\mathrm{~m}$ & $500 \mathrm{~m}$ \\
\hline Buildings & Total buildings area ${ }^{\mathrm{b}}$ & $0-40190$ & 1591.8 & $\mathrm{~m}^{2}$ & $500 \mathrm{~m}$ \\
\hline$V C F$ & Tree cover from Landsat $(2001)^{\mathrm{f}}$ & $0-99$ & 29.9 & $\%$ & $30 \mathrm{~m}$ \\
\hline$N D V I$ & NDVI from Landsat (1987) & $0.20-0.66$ & 0.30 & $0-1$ & $30 \mathrm{~m}$ \\
\hline
\end{tabular}

Explanatory variables in species distribution models are set in italics

${ }^{\text {a }}$ Hijmans et al. (2005)

${ }^{\mathrm{b}}$ Regione Autonoma Valle d'Aosta

${ }^{\mathrm{c}}$ European Soil Bureau (1999)

${ }^{\mathrm{d}}$ European Environment Agency (2013)

${ }^{\mathrm{e}}$ ISTAT (2012)

${ }^{\mathrm{f}}$ Sexton et al. (2013)

correlation between AI and WorldClim variables was always higher than 0.95 (e.g., $R=-0.995$ vs. mean annual temperature, $R=0.993$ vs. annual precipitation, $R=-0.962$ vs. GDD).

$\mathrm{AI}$ was the most important predictor for the current distribution of both pine and oak (Table 2), with higher occurrence probability at low water balance levels (Figure S2). However, MARS captured a reduced probability of occurrence for Scots pine at very low values of the aridity index (i.e., very dry sites). Beyond aridity, variables associated to high probability of Scots pine occurrence were southness, TPI, population change, building density, and past fires - the last two only in the ANN model. Soil erosion, NDVI, and road density (in the ANN model) decreased the probability of pine presence (Figure S2a). Explanatory variables of oak distribution 
Table 2 Variable importance ( $0-1)$ for SDM of current Scots pine and downy oak distribution fitted by generalized linear model (GLM), artificial neural network (ANN), and multiple adaptive regression spline (MARS)

\begin{tabular}{|c|c|c|c|c|c|c|}
\hline \multirow[b]{2}{*}{ Variable } & \multicolumn{3}{|c|}{ Scots pine } & \multicolumn{3}{|c|}{ Downy oak } \\
\hline & GLM & MARS & ANN & GLM & MARS & ANN \\
\hline AI & 0.650 & 0.645 & 0.733 & 0.848 & 0.830 & 1.000 \\
\hline Slope & 0.000 & 0.086 & 0.006 & 0.038 & 0.087 & 0.023 \\
\hline TPI & 0.145 & 0.162 & 0.000 & 0.099 & 0.103 & 0.000 \\
\hline Southness & 0.180 & 0.393 & 0.283 & 0.210 & 0.269 & 0.220 \\
\hline ATC & 0.000 & 0.017 & 0.000 & 0.078 & 0.042 & 0.000 \\
\hline AWC & 0.000 & 0.000 & 0.000 & 0.000 & 0.000 & 0.000 \\
\hline DR & 0.000 & 0.000 & 0.000 & 0.251 & 0.138 & 0.000 \\
\hline ERO & 0.000 & 0.000 & 0.000 & 0.000 & 0.000 & 0.000 \\
\hline $\mathrm{OC}$ & 0.000 & 0.000 & 0.000 & 0.044 & 0.000 & 0.000 \\
\hline VS & 0.000 & 0.000 & 0.000 & 0.160 & 0.000 & 0.000 \\
\hline Avalanches & 0.000 & 0.000 & 0.000 & 0.000 & 0.000 & 0.000 \\
\hline Wildfires & 0.010 & 0.000 & 0.000 & 0.000 & 0.000 & 0.000 \\
\hline Erosion & 0.000 & 0.061 & 0.319 & 0.011 & 0.028 & 0.109 \\
\hline Depop & 0.069 & 0.029 & 0.000 & 0.027 & 0.041 & 0.000 \\
\hline Roads & 0.000 & 0.000 & 0.459 & 0.016 & 0.029 & 0.159 \\
\hline Buildings & 0.000 & 0.017 & 0.367 & 0.027 & 0.155 & 0.201 \\
\hline $\mathrm{VCF}$ & 0.000 & 0.028 & 0.018 & 0.000 & 0.024 & 0.023 \\
\hline NDVI & 0.134 & 0.093 & 0.000 & 0.006 & 0.074 & 0.000 \\
\hline
\end{tabular}

Codes for explanatory variables are given in Table 1

exhibited a similar behavior: southness and TPI, but also slope, soil depth, and soil temperature class were associated to high presence probability, while road and building densities produced a low presence probability (Figure $\mathrm{S} 2 \mathrm{~b}$ ).

The ensemble models were successfully cross-validated ( $\mathrm{AUC}=0.865$ for pine and 0.944 for oak) and correctly predicted most observations (sensitivity $=83.4$ and $96.9 \%$, specificity $=72.7$ and $80.9 \%$, respectively) (Fig. 2). Residuals were immune from spatial autocorrelation and trends against any of the predictors.

In 2080 (SRES A1B emission scenario, continuing population trend), the mean probability of occurrence of Scots pine declined slightly ( 0.33 vs. a current 0.36 across the whole study area) (Fig. 3). However, it increased under the intense land use scenario $(0.45)$ (Fig. 4). The area with a probability of occurrence of Scots pine $>0.6$ decreased from 8700 to 8000 ha under the climate warming scenario and increased to 8800 ha under climate warming + intense land use. The probability of occurrence of Scots pine always declined at lower elevations and increased at higher ones (Fig. 5); mean elevation of simulated presence points shifted from 1328 to $1528 \mathrm{~m}$ a.s.l. under climate warming and to $1473 \mathrm{~m}$ a.s.l. under climate warming intense land use, i.e., an upward shift of the potential niche of 200 and $145 \mathrm{~m}$, respectively.
Oak increased its probability of occurrence under all scenarios (6100 ha under current conditions, 10,100 ha under climate change only, and 14,700 ha under climate change + intense land use). Mean elevation of simulated presence points (probability of occurrence $>0.6$ ) shifted from 705 to 922 and $933 \mathrm{~m}$ a.s.l., respectively, i.e., an upward shift of 215 and $222 \mathrm{~m}$.

The area of Scots pine pixels classified as decline was 147 ha in year 2003 and 102 ha in year 2006. However, in either year we did not observe a significant difference between decline and non-decline pixels in the modeled probability of occurrence of Scots pine for 2080 (Fig. 6).

\section{Discussion}

Published models of Scots pine distribution under scenarios of climate change have produced contrasting results (e.g., Casalegno et al. 2011; Meier et al. 2011), probably as a result of different datasets and processes being included or not in the models (e.g., dispersal constraints, biotic competition, choice of climate, and drought-related variables).

Many processes are at work in determining pine decline. Drought is either a direct or a predisposing factor of mortality (Rebetez and Dobbertin 2004; Choat et al. 2013). At low elevations, Scots pine reaches more rapidly decay stages, since trees weakened by drought are easily killed by "inciting" or "contributing" biotic agents (Dobbertin et al. 2005; Bigler et al. 2006; Vacchiano et al. 2012). Also, land use change may eventually result in competitive exclusion of light-demanding Scots pine.

Climate warming and drought are related (i.e., the frequency of drought spells is expected to increase under climate change: Allen et al. 2010); however, extreme drought events may be more important than average climate trends in determining plant population viability (Katz and Brown 1992; Bréda and Badeau 2008), and they can induce shifts in species composition and distribution (Jentsch et al. 2007).

In order to take into account the different factors governing drought sensitivity, we included in our models its meteorological, topographic, and soil-related component. At the resolution and extent analyzed, the probability of occurrence of Scots pine increased under climatic and topographic aridity. This is consistent with the biogeography of the species that forms pure stands in most inner-Alpine valleys such as the study area, preferentially on south-facing slopes and ridge positions (Ozenda 1985). Accordingly, low aridity reduced the probability of presence of Scots pine. In Aosta valley, temperature and precipitation are strongly correlated to elevation (which for this reason was excluded from the analysis); therefore, the AI variable contained also information regarding the upper elevational limits of the habitat suitable for Scots pine. 
a

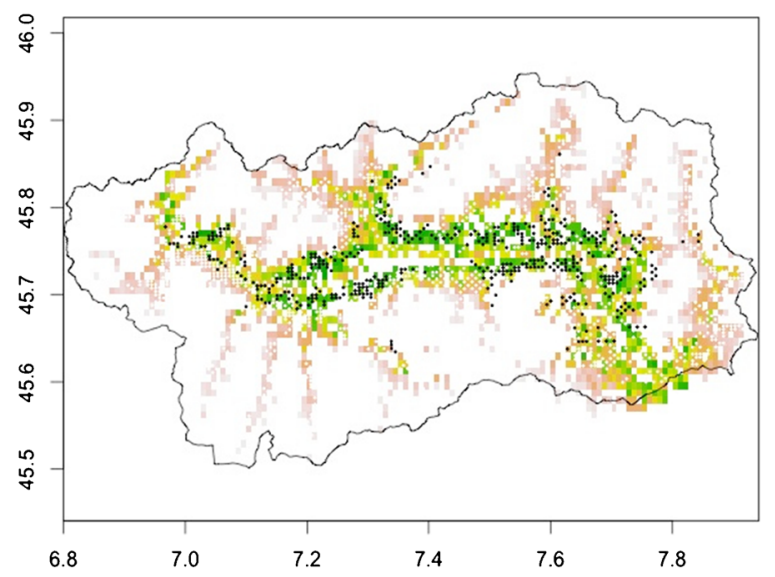

b

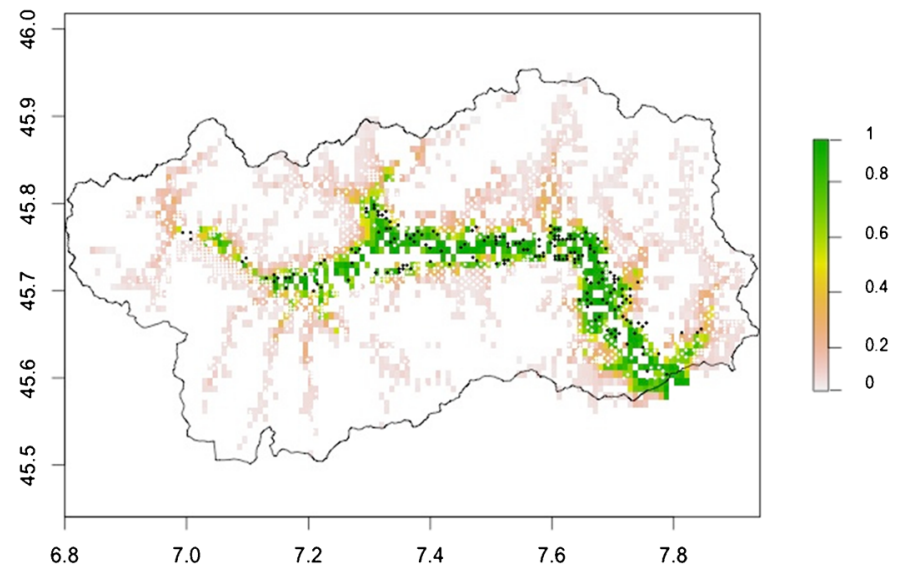

Fig. 2 Occurrence probability ( $0-1)$ of a Scots pine and $\mathbf{b}$ downy oak under current climate. Ensemble model (mean of GLM, MARS, and ANN). Presence points from the regional forest inventory in black

Another important driver of Scots pine occurrence was biotic competition, as expressed by NDVI of the forest canopy. As expected, the early seral pine cannot establish successfully under thick canopy cover (Vickers 2000). In contrast, it can also establish successfully on non-forested land, such as abandoned pastures and meadows (Poyatos et al. 2003), but this process could not be taken into consideration in future simulations, since our correlative models were calibrated on current vegetation conditions only.

In addition to topo-climatic and competition variables that are routinely assessed in SDM, we also evaluated the effect of soil properties (albeit using a coarse resolution and dummy coding) and natural and anthropogenic disturbances (Matias and Jump 2012). Scots pine did not exhibit any soil preference, consistently with its edaphic plasticity (Médail 2001). However, its occurrence was moderately associated to the absence of steep slopes and severe land erosion, which should be adverse to permanent vegetation cover, and to recurring wildfires. Wildfire polygons were not labeled as surface or crown fires; however, surface fires are more common in the study area, especially at low elevations on south-facing slopes (Vacchiano et al. 2013).

We also evaluated the effect of human land use on species distribution by using proxy variables (Garbarino et al. 2009). Increased population and road density resulted in increased occurrence of Scots pine. Management practices such as timber harvesting, litter collection, and forest grazing may in fact prevent succession to more competitive late-seral species (Weber et al. 2008; Gimmi et al. 2010). The association between pine and population/road density may also be due to recent establishment of Scots pine after agricultural abandonment (Poyatos et al. 2003). Building density was negatively correlated to the probability of occurrence of both Scots pine and downy oak, likely due to the spatial segregation of forests vs. developed or urbanized areas in the main valley.

These factors help explain the response of Scots pine distribution in 2080 under the A1B warming scenario, i.e., a modest reduction of habitat suitability, but a significant
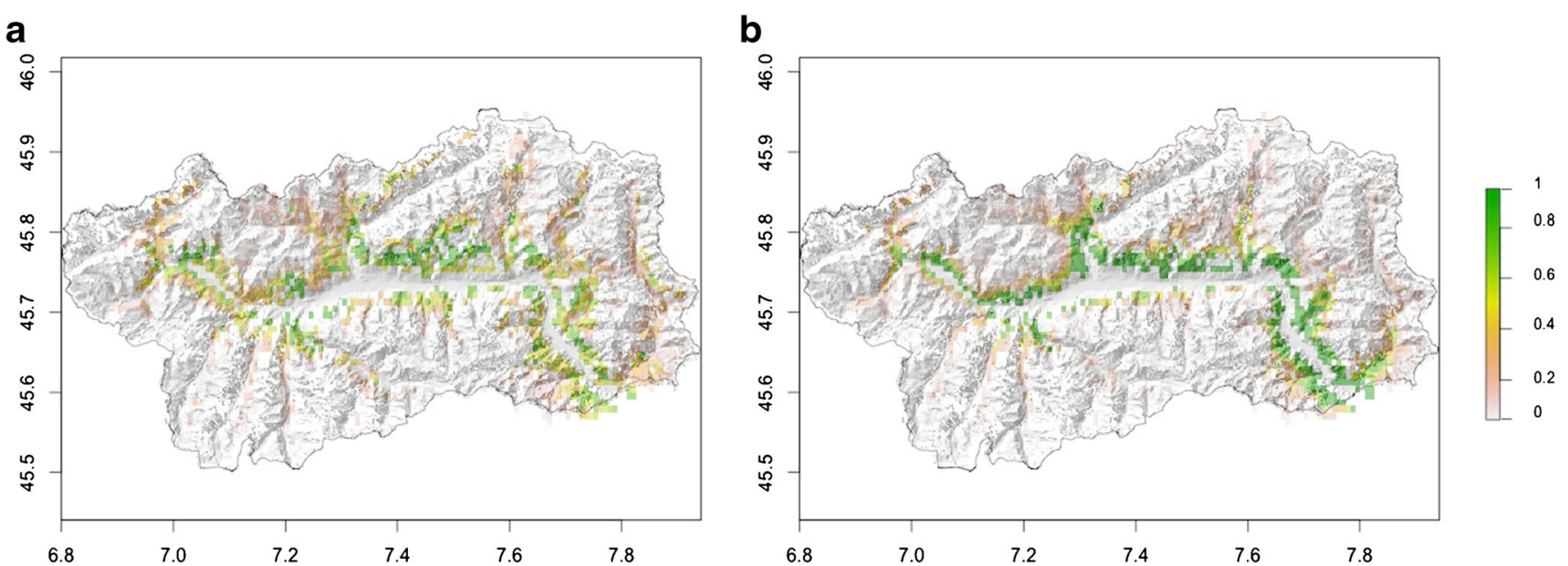

Fig. 3 Occurrence probability (0-1) of a Scots pine and $\mathbf{b}$ downy oak under 2080 climate and current land use scenario. Ensemble model (mean of GLM, MARS, and ANN) 
a

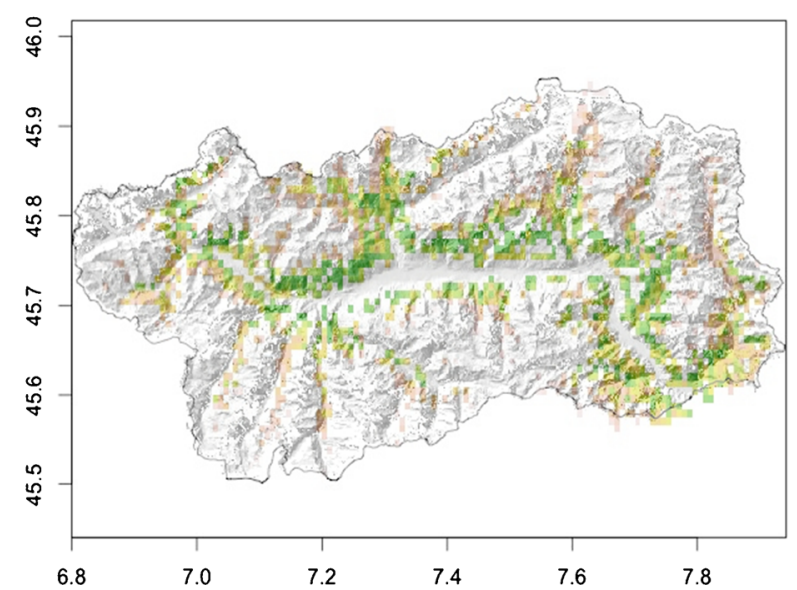

b

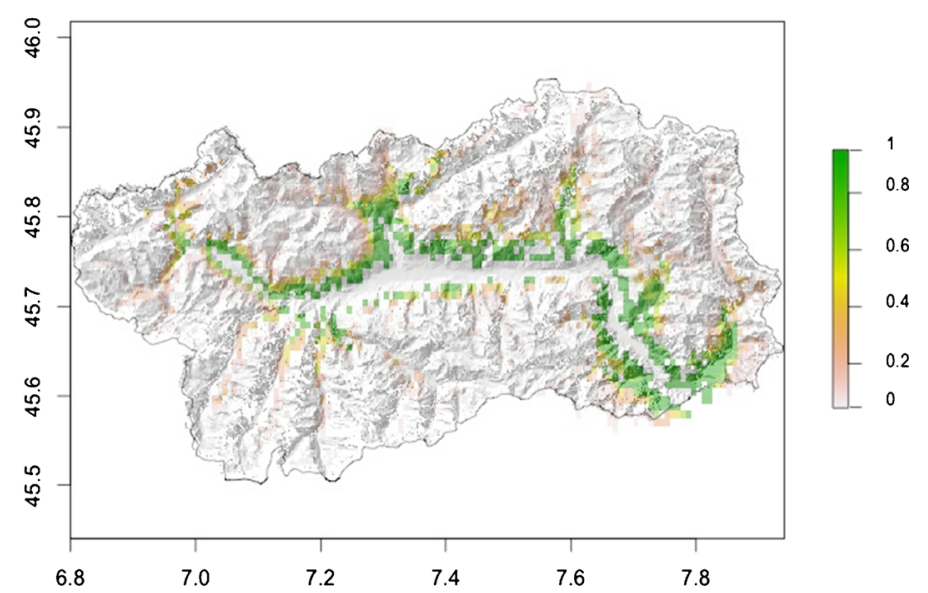

Fig. 4 Occurrence probability (0-1) of a Scots pine and b downy oak under 2080 climate and intensive land use scenario. Ensemble model (mean of GLM, MARS, and ANN)

increase of its optimum elevation. At low elevations, in fact, aridity could reach the lower limits for the species to persist, as

a


suggested by the MARS response curve (Garzon et al. 2008). This change is partially counteracted in a scenario where land

b


Fig. 5 Change in probability of occurrence (2080-current) of a Scots pine and b downy oak for different elevation classes under 2080 climate (above) and 2080 climate + intensive land use scenario (below) 
Fig. 6 Change in probability of occurrence (2080-current) of Scots pine for decline and non-decline pixels in dry years 2003 (left) and 2006 (right), under 2080 climate (above) and 2080 climate + intensive land use scenario (below) a

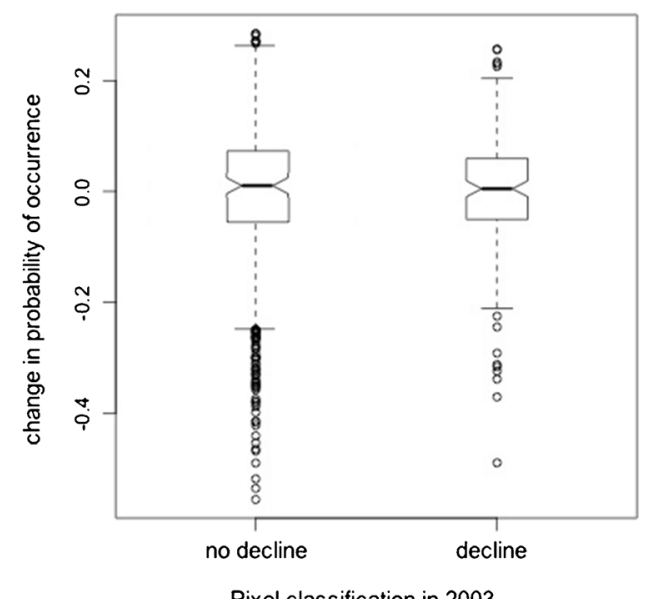

Pixel classification in 2003

b 2080 climate and intensive land use

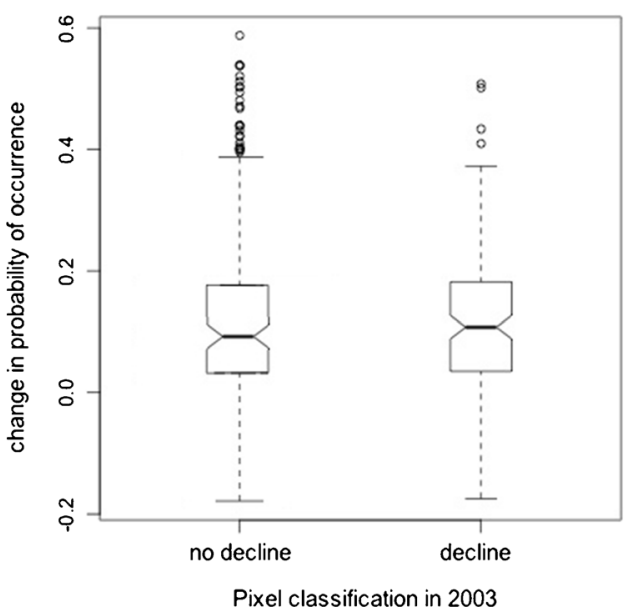

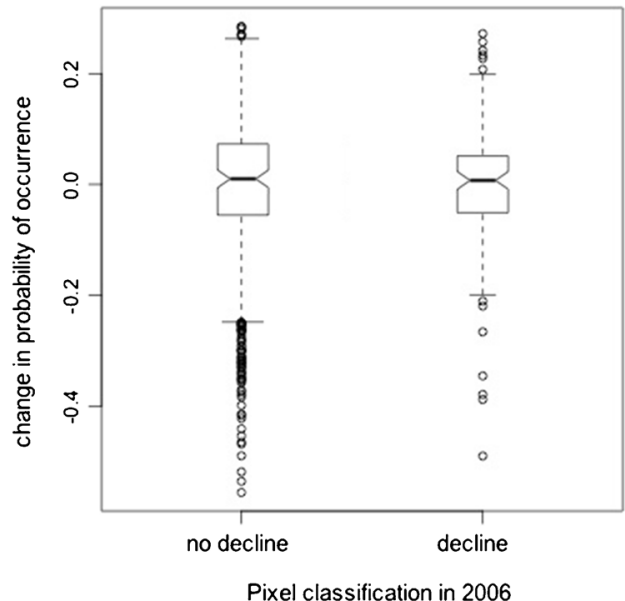

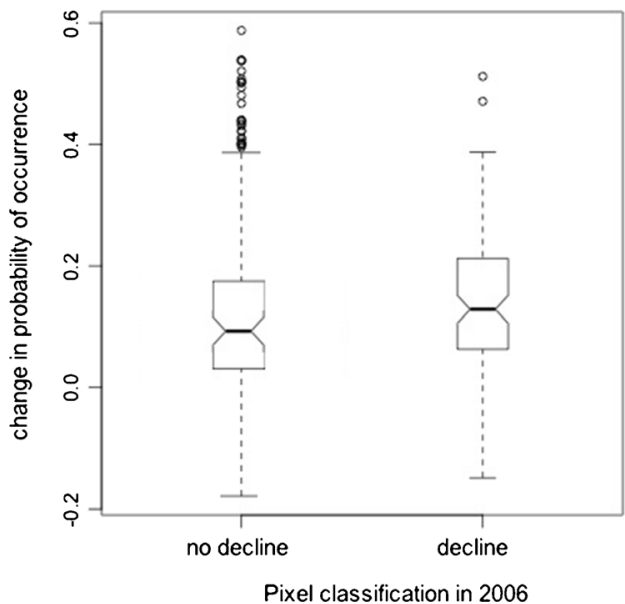

abandonment is avoided: in this case, the probability of occurrence of Scots pine would still decrease at low elevations but, on average, the human factor could be sufficient to prevent the decline of Scots pine throughout its current distribution. This analysis is correlative and does not explore the physiological and successional processes behind such land use/climate change tradeoff. However, it is indicative of the fact that land use changes can be as strong as climate change in determining future species composition and dominance of mountain forests (Dirnböck et al. 2003) and that they deserve a deeper attention in modeling species' response to future climate conditions.

The distribution of downy oak shared the same topoclimatic features as Scots pine (high aridity/low elevation, southern aspects, low erosion, high soil temperature) but was also associated to lower land use intensity (road density) and higher soil depth. Canopy density (NDVI) and natural disturbances were not influential, since downy oak is more shade-tolerant than pine (Monnier et al. 2013). The response of downy oak to climate warming was different from Scots pine and produced an increased probability of occurrence throughout the study region. Previous research has demonstrated that downy oak is better adapted than Scots pine to both short- and long-term drought, due to its different physiological responses, i.e., stomata closure, resistance to embolism, and seedling vitality (Eilmann et al. 2006; Poyatos et al. 2008; Morán-López et al. 2012).

Population change was not among the most important predictors of current downy oak distribution. However, we detected a moderate association between population increase and higher probability of occurrence of oak. This can be due either to the practice of coppicing oaks for firewood or to the fact that depopulated areas are located in the remotest part of lateral valleys, where elevation and sites are far below optimum for downy oak.

The use of ensemble modeling is justified by the need to reduce model uncertainty due to different modeling approaches (Marmion et al. 2003). Ensemble models in 
biomod 2 are obtained by averaging model predictions and excluding models with low predictive power (AUC $<0.75$ ); model predictions are weighted by the AUC of their respective modeling algorithm. In this study, all three model algorithms produced an AUC $>0.75$. However, differences in importance of explanatory variables and shape of response curves were apparent. MARS are more flexible than GLM as they are fit using piecewise linear splines and are particularly useful when assuming that the shape of species' responses is not linear (Leathwick et al. 2005). ANN, on the other hand, are not based on specific distribution functions of the response. They are robust to noisy and non-linear responses and allow for categorical predictors (such as soil characteristics in this study). Therefore, they are particularly appropriate in an exploratory context. On the other hand, they are sensitive to multicollinearity and prone to overfitting, and interpretation of causal relationships for individual predictors is not straightforward (Manel et al. 1999). The differences are apparent in species response curves (Figure S2), with MARS and ANN capable of detecting non-linear responses to some explanatory variables that were not picked up by GLM, despite a similar predictive performance. This is reflected by the higher importance of some explanatory variables, such as roads, buildings, TPI, or erosion, under models capable of detecting non-linear species responses (Table 2).

Finally, contrary to our expectations, we did not detect any overlap between drought-induced Scots pine decline in years 2003 and 2006 and change in occurrence probability under a warming scenario. Widespread tree mortality can occur under extreme dry spells, but it is uncertain whether one or two extreme years are sufficient to trigger major shifts in forest composition (e.g., Vicente-Serrano et al. 2013). The effect of extreme years on the realized niche of Scots pine will likely depend on the frequency and severity of droughts, rather than on decadal climate means such as the ones we used in our projections. Other parameters might be important in their extreme yearly or seasonal values, such as high precipitation events promoting a new generation after a mortality episode (Matias and Jump 2012), late frost preventing uphill expansion of sensitive species such as downy oak (Burnand 1976), and natural disturbances such as large, stand-replacing fires (Moser et al. 2010).

What is certain, however, is that downy oak is equipped with better adaptations to drought and is likely to replace Scots pine at lower elevations under a warming scenarios, whereby an increased frequency of droughts is to be expected (Dai 2012). Management actions have the potential to mitigate this shift (Vilà-Cabrera et al. 2013), e.g., thinning to 40-60\% initial basal area to mitigate drought effects on Scots pine on xeric sites (Giuggiola et al. 2013). However, effects of management actions must be more thoroughly explored to evaluate tradeoffs with each species' resistance and resilience in the face of climate forcing.
Acknowledgments The authors thank Nicklaus E. Zimmerman, Jordi Martinez Vilalta, and Heike Lischke for the useful suggestions on the modeling approach, Regione Autonoma Valle d'Aosta for data provision, and Daniele Castagneri, Davide Ascoli, and two anonymous reviewers for helping to improve earlier versions of the paper.

Funding Funding to the principal investigator was provided by the DISAFA, University of Torino, and by the Italian Ministry of Education, University and Research.

\section{References}

Allen CD, Macalady AK, Chenchouni H, Bachelet D, McDowell NG, Vennetier M, Kitzberger T, Rigling A, Breshears DD, Hogg EHT, Gonzalez P, Fensham R, Zhang Z, Castro J, Demidova N, Lim JH, Allard G, Running SW, Semerci A, Cobb NS (2010) A global overview of drought and heat-induced tree mortality reveals emerging climate change risks for forests. For Ecol Manage 259:660-684

Araujo M, New M (2007) Ensemble forecasting of species distributions. Trends Ecol Evol 22:42-47

Bagnouls F, Gaussen H (1957) Les climats biologiques et leur classification. Ann Geophys 66:193-220

Biancotti A, Bellardone G, Bovo S, Cagnazzi B, Giacomelli L, Marchisio C (1998) Distribuzione regionale di piogge e temperature. Regione Piemonte, Torino

Bigler C, Bräker OU, Bugmann H, Dobbertin M, Rigling A (2006) Drought as an inciting mortality factor in Scots pine stands of the Valais, Switzerland. Ecosystems 9:330-343

Bréda N, Badeau V (2008) Forest tree responses to extreme drought and some biotic events: towards a selection according to hazard tolerance? Compt Rendus Geosci 340:651-662

Burnand J (1976) Quercus pubescens-Wälder und ihre ökologischen Grenzen im Wallis (Zentralalpen). Dissertation, ETH Zürich

Burns RM, Honkala BH (1990) Silvics of North America. Volume 1. Conifers. USDA Forest Service, Washington DC

Camerano P, Terzuolo PG, Varese P (2007) I tipi forestali della Valle d'Aosta. Compagnia delle Foreste, Arezzo

Caplat P, Lepart J, Marty P (2006) Landscape patterns and agriculture: modelling the long-term effects of human practices on Pinus sylvestris spatial dynamics (Causse Mejean, France). Landsc Ecol 21:657-670

Carnicer J, Coll M, Pons X, Ninyerola M, Vayreda J, Peñuelas J (2014) Large-scale recruitment limitation in Mediterranean pines: the role of Quercus ilex and forest successional advance as key regional drivers. Glob Ecol Biogeogr 23:371-384

Casalegno S, Amatulli G, Bastrup-Birk A, Durrant TH, Pekkarinen A (2011) Modelling and mapping the suitability of European forest formations at 1-km resolution. Eur J For Res 130:971-981

Chander G, Markham BL, Helder DL (2009) Summary of current radiometric calibration coefficients for Landsat MSS, TM, ETM+, and EO-1 ALI sensors. Remote Sens Environ 113:893-903

Chang C-R, Lee P-F, Bai M-L, Lin T-T (2004) Predicting the geographical distribution of plant communities in complex terrain - a case study in Fushian Experimental Forest, northeastern Taiwan. Ecography 27:577-588

Chmura DJ, Anderson PD, Howe GT, Harrington CA, Halofsky JE, Peterson DL, Shaw DC, St.Clair JB (2011) Forest responses to climate change in the northwestern United States: ecophysiological foundations for adaptive management. For Ecol Manage 261:11211142

Choat B, Jansen S, Brodribb TJ, Cochard H, Delzon S, Bhaskar R, Bucci SJ, Feild TS, Gleason SM, Hacke UG, Jacobsen AL, Lens F, Maherali H, Martínez-Vilalta J, Mayr S, Mencuccini M, Mitchell 
PJ, Nardini A, Pittermann J, Pratt RB, Sperry JS, Westoby M, Wright IJ, Zanne AE (2013) Global convergence in the vulnerability of forests to drought. Nature 491:752-755

Costantini EAC, Urbano F, L'Abate G (2004) Soil regions of Italy. CRAISSDS, Firenze

Dahl E (1998) The phytogeography of northern Europe: British Isles. Fennoscandia and adjacent areas. Cam-bridge University Press, Cambridge

Dai A (2012) Increasing drought under global warming in observations and models. Nature Clim Change 3:52-58

Debain S, Curt T, Lepart J, Prevosto B (2003) Reproductive variability in Pinus sylvestris in southern France: implications for invasion. J Veg Sci 14:509-516

Dirnböck T, Dullinger S, Grabherr G (2003) A regional impact assessment of climate and land-use change on alpine vegetation. J Biogeogr 30:401-417

Dobbertin M, Mayer P, Wohlgemuth T, Feldmeyer-Christe E, Graf U, Zimmermann NE, Rigling A (2005) The decline of Pinus sylvestris L. forests in the Swiss Rhone valley-a result of drought stress? Phyton 45:153-156

Dobbertin M, Wermelinger B, Bigler C, Bürgi M, Carron M, Forster B, Gimmi U, Rigling A (2007) Linking increasing drought stress to Scots pine mortality and bark beetle infestations. Sci World J 7:231-239

Eilmann B, Weber P, Rigling A, Eckstein D (2006) Growth reactions of Pinus sylvestris L. and Quercus pubescens Willd. to drought years at a xeric site in Valais, Switzerland. Dendrochronol 23:121-132

Eilmann B, Zweifel R, Buchmann N, Fonti P, Rigling A (2009) Droughtinduced adaptation of the xylem in Scots pine and pubescent oak. Tree Physiol 29:1011-1020

Eilmann B, Zweifel R, Buchmann N, Graf Pannatier E, Rigling A (2011) Drought alters timing, quantity, and quality of wood formation in Scots pine. J Exp Bot 62:2763-2771

Elith J, Leathwick JR (2009) Species distribution models: ecological explanation and prediction across space and time. Annu Rev Ecol Evol Syst 40:677-697

European Environment Agency (2013) Corine land cover 1990 raster data, version 17. [online] URL: http://www.eea.europa.eu/data-andmaps/data/corine-land-cover-1990-raster-3. Last accessed: November 4, 2014

European Soil Bureau (1999) The European Soil Database, version 1.0. CD-ROM. EU Joint Research Centre, Ispra

Farrell EP, Führer E, Ryan D, Andersson F, Hüttl RF, Piussi P (2000) European forest ecosystems: building the future on the legacy of the past. For Ecol Manage 132:5-20

Fronzek S, Carter TR, Jylhä K (2011) Representing two centuries of past and future climate for assessing risks to biodiversity in Europe. Glob Ecol Biogeogr 21:19-35

Fung T, Ledrew E (1988) The determination of optimal threshold levels for change detection using various accuracy indices. Photogramm Eng Remote Sens 54:1449-1454

Galiano L, Martínez-Vilalta J, Lloret F (2010) Drought-induced multifactor decline of Scots pine in the Pyrenees and potential vegetation change by the expansion of co-occurring oak species. Ecosystems 13:978-991

Galiano L, Martínez-Vilalta J, Eugenio M, Granzow-De La Cerda Í, Lloret F (2013) Seedling emergence and growth of Quercus spp. following severe drought effects on a Pinus sylvestris canopy. J Veg Sci 24:580-588

Garbarino M, Weisberg PJ, Motta R (2009) Interacting effects of physical environment and anthropogenic disturbances on the structure of European larch (Larix decidua Mill.) forests. For Ecol Manage 257:1794-1802

Garzon MB, Sanchez de Dios R, Sainz Ollero H (2008) The evolution of the Pinus sylvestris L. area in the Iberian Peninsula from the last glacial maximum to 2100 under climate change. The Holocene 18: 705-714
Gasparini P, Tabacchi G (2011) L'Inventario Nazionale delle Foreste e dei serbatoi forestali di Carbonio INFC 2005. Secondo inventario forestale nazionale italiano. Metodi e risultati. Ministero delle Politiche Agricole, Alimentari e Forestali; Corpo Forestale dello Stato. Consiglio per la Ricerca e la Sperimentazione in Agricoltura, Unità di ricerca per il Monitoraggio e la Pianificazione Forestale. Edagricole-Il Sole 24 ore, Bologna.

Gimmi U, Bürgi M, Stuber M (2007) Reconstructing anthropogenic disturbance regimes in forest ecosystems: a case study from the Swiss Rhone valley. Ecosystems 11:113-124

Gimmi U, Wohlgemuth T, Rigling A, Hoffmann CW, Bürgi M (2010) Land-use and climate change effects in forest compositional trajectories in a dry central-alpine valley. Ann For Sci 67:701p1-701p9

Giuggiola A, Bugmann H, Zingg A, Dobbertin M, Rigling A (2013) Reduction of stand density increases drought resistance in xeric Scots pine forests. For Ecol Manage 310:827-835

Gobet E Tinner W, Hochuli PA, van Leeuwen JFN, Ammann B (2003) Middle to late Holocene vegetation history of the Upper Engadine (Swiss Alps): the role of man and fire. Veg Hist Archaeobot 12:143163

Gonthier P, Giordano L, Nicolotti G (2010) Further observations on sudden diebacks of Scots pine in the European Alps. For Chron 86:110-117

Guisan A, Weiss SB, Weiss AD (1999) GLM versus CCA spatial modeling of plant species distribution. Plant Ecol 143:107-122

Hijmans RJ, Cameron SE, Parra JL, Jones PG, Jarvis A (2005) Very high resolution interpolated climate surfaces for global land areas. Int $\mathrm{J}$ Climatol 25:1965-1978

ISTAT (2012) 14mo censimento generale della popolazione e delle abitazioni. [online] URL: http://dawinci.istat.it/MD/. Last accessed: November 4, 2014

Jentsch A, Kreyling J, Beierkuhnlein C (2007) A new generation of climate-change experiments: events, not trends. Frontiers Ecol Environ 5:365-374

Katz RW, Brown BG (1992) Extreme events in a changing climate: variability is more important than averages. Clim Change 21:289 302

Kräuchi N, Brang P, Schonenberger W (2000) Forests of mountainous regions: gaps in knowledge and research needs. For Ecol Manage 132:73-82

Leathwick JR, Rowe D, Richardson J, Elith J, Hastie T (2005) Using multivariate adaptive regression splines to predict the distributions of New Zealand's freshwater diadromous fish. Freshwater Biol 50: 2034-2052

Manel S, Dias JM, Buckton ST, Ormerod SJ (1999) Alternative methods for predicting species distribution: an illustration with Himalayan river birds. J Appl Ecol 36:734-747

Marmion M, Parviainen M, Luoto M, Heikkinen RK, Thuiller W (2003) Evaluation of consensus methods in predictive species distribution modeling. Divers Distrib 15:59-69

Martínez-Vilalta J, Piñol J (2002) Drought-induced mortality and hydraulic architecture in pine populations of the NE Iberian Peninsula. For Ecol Manage 161:247-256

Matias L, Jump AS (2012) Interactions between growth, demography and biotic interactions in determining species range limits in a warming world: the case of Pinus sylvestris. For Ecol Manage 282:10-22

Matias L, Jump AS (2014) Impacts of predicted climate change on recruitment at the geographical limits of Scots pine. J Exp Bot 65: 299-310

Médail F (2001) Biogéographie, écologie et valeur patrimoniale des forêts de pin sylvestre (Pinus sylvestris L.) en région méditerranéenne. For Médit 22:5-22

Meier ES, Lischke H, Schmatz DR, Zimmermann NE (2011) Climate, competition and connectivity affect future migration and ranges of European trees. Glob Ecol Biogeogr 21:164-178

Mirov NT (1967) The genus Pinus. Ronald Press Company, New York 
Monnier Y, Bousquet-Mélou A, Vila B, Prévosto B, Fernandez C (2013) How nutrient availability influences acclimation to shade of two (pioneer and late-successional) Mediterranean tree species? Eur J For Res 132:325-333

Morán-López T, Poyatos R, Llorens P, Sabate S (2012) Effects of past growth trends and current water use strategies on Scots pine and pubescent oak drought sensitivity. Trees 133:369-382

Moriondo M, Good P, Durao R, Bindi M, Giannakopoulos C, Corte-Real J (2006) Potential impact of climate change on fire risk in the Mediterranean area. Clim Res 31:85-95

Morisette JT, Khorram S (2000) Accuracy assessment curves for satellitebased change detection. Photogramm Eng Remote Sens 66:875880

Moser B, Temperli C, Schneiter G, Wohlgemuth T (2010) Potential shift in tree species composition after interaction of fire and drought in the Central Alps. Eur J For Res 129:625-633

Nardini A, Pitt F (1999) Drought resistance of Quercus pubescens as a function of root hydraulic conductance, xylem embolism and hydraulic architecture. New Phytol 143:485-493

Oberhuber W, Swidrak I, Pirkebner D, Gruber A (2011) Temporal dynamics of nonstructural carbohydrates and xylem growth in Pinus sylvestris exposed to drought. Can J For Res 41:1590-1597

Ozenda P (1985) La vegetation de la chaine alpine dans l'espace montagnard europeen. Masson, Paris

Peel MC, Finlayson BL, McMahon TA (2007) Updated world map of the Köppen-Geiger climate classification. Hydrol Earth Sys Sci 11: 1633-1644

Pettorelli N, Vik JO, Mysterud A, Gaillard J-M, Tucker CJ, Stenseth NC (2005) Using the satellite-derived NDVI to assess ecological responses to environmental change. Trends Ecol Evol 20:503-510

Picon-Cochard C, Coll L, Balandier P (2006) The role of below-ground competition during early stages of secondary succession: the case of 3-year-old Scots pine (Pinus sylvestris L.) seedlings in an abandoned grassland. Oecologia 148:373-383

Poyatos R, Latron J, Llorens P (2003) Land use and land cover change after agricultural abandonment: the case of a Mediterranean mountain area (Catalan Pre-Pyrenees). Mt Res Dev 23:362-368

Poyatos R, Llorens P, Piñol J, Rubio C (2008) Response of Scots pine (Pinus sylvestris L.) and pubescent oak (Quercus pubescens Willd.) to soil and atmospheric water deficits under Mediterranean mountain climate. Ann For Sci 65:306. doi: 10.1051/forest:2008003

Development Core Team R (2013) R: a language and environment for statistical computing. R Foundation for Statistical Computing, Vienna

Raible CC, Casty C, Luterbacher J, Pauling A, Esper J, Frank DC, Büntgen U, Roesch AC, Tschuck P, Wild M, Vidale P-L, Schär C, Wanner H (2006) Climate variability-observations, reconstructions, and model simulations for the Atlantic-European and Alpine region from 1500-2100 AD. Clim Change 79:9-29

Rebetez M, Dobbertin M (2004) Climate change may already threaten Scots pine stands in the Swiss Alps. Theor Appl Climatol 79:1-9

Richardson DM (1998) Ecology and biogeography of Pinus. Cambridge University Press, Cambridge

Rigling A, Eilmann B, Koechli R, Dobbertin M (2010) Mistletoe-induced crown degradation in Scots pine in a xeric environment. Tree Physiol 30:845-852

Rigling A, Bigler C, Eilmann B, Feldmeyer-Christe E, Gimmi U, Ginzler C, Graf U, Mayer P, Vacchiano G, Weber P, Wohlgemuth T, Zweifel R, Dobbertin M (2013) Driving factors of a vegetation shift from Scots pine to pubescent oak in dry alpine forests. Glob Change Biol 19:229-240

Rohde K (2005) Nonequilibrium ecology. Cambridge University Press, Cambridge

Sakai A, Okada S (1971) Freezing resistance of conifers. Silvae Genetica 20:91-97
Sangüesa-Barreda G, Linares JC, Camarero JJ (2013) Drought and mistletoe reduce growth and water-use efficiency of Scots pine. For Ecol Manage 296:1-10

Sexton JO, Song X-P, Feng M, Noojipady P, Anand A, Huang C, Kim DH, Collins KM, Channan S, DiMiceli C, Townshend JR (2013) Global, 30-m resolution continuous fields of tree cover: Landsatbased rescaling of MODIS vegetation continuous fields with lidarbased estimates of error. International Journal of Digital Earth 6: $427-448$

Singh BP, Cowie AL, Chan KY (2011) Soil health and climate change. Springer, Berlin

Sokal RR, Rohlf FJ (1995) The principles and practice of statistics in biological research. Freeman and Co, New York

Sterck FJ, Zweifel R, Sass-Klaassen U, Chowdhury Q (2008) Persisting soil drought reduces leaf specific conductivity in Scots pine (Pinus sylvestris) and pubescent oak (Quercus pubescens). Tree Physiol 28: 529-536

Tetrarca S, Spinelli F, Cogliani E, Mancini M (1999) Profilo climatico dell'Italia. ENEA, Roma

Thabeet A, Vennetier M, Gadbin-Henry C, Denelle N, Roux M, Caraglio Y, Vila B (2010) Response of Pinus sylvestris L. to recent climatic events in the French Mediterranean region. Trees 23:843-853

Thuiller W, Georges D, Engler R (2013) Package biomod2. http://cran. open-source-solution.org/web/packages/biomod2. Accessed 7 Dec 2013

Tucker CJ (1979) Red and photographic infrared linear combinations for monitoring vegetation. Remote Sens Environ 8:127150

Urbieta IR, García LV, Zavala MA, Marañón T (2011) Mediterranean pine and oak distribution in southern Spain: is there a mismatch between regeneration and adult distribution? J Veg Sci 22:18-31

Vacchiano G, Garbarino M, Borgogno Mondino E, Motta R (2012) Evidences of drought stress as a predisposing factor to Scots pine decline in Valle d'Aosta (Italy). Eur J For Res 131:989-1000

Vacchiano G, Motta R, Long JN, Shaw JD (2008) A density management diagram for Scots pine (Pinus sylvestris L.): a tool for assessing the forest's protective effect. For Ecol Manage 255:2542-2554

Vacchiano G, Lonati M, Berretti R, Motta R (2013) Drivers of Pinus sylvestris $\mathrm{L}$. regeneration following small, high-severity fire in a dry, inner-alpine valley. Plant Biosystems, in press. doi: 10.1080/ 11263504.2013 .819821

Vicente-Serrano SM, Gouveia C, Camarero JJ, Beguería S, Trigo R, López-Moreno JI, Azorín-Molina C, Pasho E, Lorenzo-Lacruz J, Revuelto J, Morán-Tejeda E, Sanchez-Lorenzo A (2013) Response of vegetation to drought time-scales across global land biomes. Proc Natl Acad Sci U S A 110:52-57

Vickers AD (2000) The influence of canopy cover and other factors upon the regeneration of Scots pine and its associated ground flora within Glen Tanar National Nature Reserve. Forestry 73:37-49

Vilà-Cabrera A, Rodrigo A, Martínez-Vilalta J, Retana J (2011) Lack of regeneration and climatic vulnerability to fire of Scots pine may induce vegetation shifts at the southern edge of its distribution. J Biogeogr 39:488-496

Vilà-Cabrera A, Martínez-Vilalta J, Galiano L, Retana J (2013) Patterns of forest decline and regeneration across Scots pine populations. Ecosystems 16:323-335

Weber P, Rigling A, Bugmann H (2008) Sensitivity of stand dynamics to grazing in mixed Pinus sylvestris and Quercus pubescens forests: a modelling study. Ecol Model 210:301-311

Wiens JJ, Ackerly DD, Allen AP, Anacker BL, Buckley LB, Cornell HV, Damschen EI, Jonathan Davies T, Grytnes JA, Harrison SP, Hawkins BA, Holt RD, McCain CM, Stephens PR (2010) Niche conservatism as an emerging principle in ecology and conservation biology. Ecol Letters 13:1310-1324 
Zavala MA, Zea E (2004) Mechanisms maintaining biodiversity in Mediterranean pine-oak forests: insights from a spatial simulation model. Plant Ecol 171:197-207

Zimmermann NE, Edwards TC, Moisen GG, Frescino TS, Blackard JA (2007) Remote sensing-based predictors improve distribution models of rare, early successional and broadleaf tree species in Utah. J Appl Ecol 44:1057-1067

Zweifel R, Rigling A, Dobbertin M (2009) Species-specific stomatal response of trees to drought $-\mathrm{a}$ link to vegetation dynamics? J Veg Sci 20:442-454 